\title{
DESCRIPTION OF THE EVENT RATE OF CONTROLLED AND UNCONTROLLED HYPERTENSION PATIENTS AT MALINGPING PUBLIC HEALTH CENTER (PUSKESMAS)
}

\author{
Mega Martin \\ Master of Public Health Study Program, Faculty of Public Health, Muhammadiyah University of Jakarta \\ Jl. KH Ahmad Dahlan, Cirendeu, East Ciputat, South Tangerang, Banten 15419
}

\begin{abstract}
The prevalence of hypertension in the world in 2000 according to WHO worldwide there were 972 million people or $26.4 \%$ of the earth's inhabitants experienced hypertension. Of the 972 million people with hypertension, 333 million are in developed countries and the remaining 63 million are in developing countries, including Indonesia. Knowing the description of the incidence of controlled and uncontrolled hypertension at the Malingping Health Center in 2021. Descriptive research design. Samples were taken using the purposive sampling technique, namely 119 patients who came for treatment at the Malingping Health Center. The results were analyzed univariately. Based on the results of the study, it can be seen from 106 respondents who were not controlled (81.1\%), while those who were controlled were 13 respondents (10.9\%). Age of hypertensive patients included in the groupage > 60 years as many as 62 samples (52.1\%). The sex of the patients was mostly female, namely 88 samples (73.9\%). The incidence of hypertension sufferers in the working area of Malingping Health Center is still uncontrolled, in the age group > 60 years and female.
\end{abstract}

Keywords: Uncontrolled, Hypertension 


\section{INTRODUCTION}

Hypertension is still a health problem in the world. This disease is also called the silent killer because it is often found without symptoms and is only realized when it has caused organ disorders. Untreated hypertension will affect all organ systems and ultimately shorten life expectancy by 10-20 years. 20 Mortality in hypertensive patients is faster if the disease is not controlled and has caused complications to several vital organs. ${ }^{9}$

Hypertension is a degenerative disease that often occurs in the community and has a fairly high mortality rate. Hypertension is still a serious public health problem because if it is not controlled it will develop and cause dangerous complications, such as stroke (brain hemorrhage), coronary heart disease, and kidney failure. ${ }^{9}$

According to Marliani (2007), hypertension is an increase in systolic pressure above 140 $\mathrm{mmHg}$ and diastolic pressure above $90 \mathrm{mmHg}$. This disease is often characterized by dizziness, often feels stiff in the back of the neck, visual disturbances, difficulty concentrating, difficulty sleeping, and often restless, but can be asymptomatic. The occurrence of hypertension is influenced by several factors, including factors that cannot be corrected such as genetics, age, gender, and factors that can be corrected such as excess salt, cholesterol, obesity, stress, smoking, caffeine, lack of movement, alcohol.

The prevalence of hypertension in the world in 2000 according to WHO worldwide there were 972 million people or $26.4 \%$ of the earth's inhabitants experienced hypertension. This figure is likely to increase to $29.2 \%$ in 2025 . Of the 972 million people with hypertension, 333 million are in developed countries and the remaining 63 million are in developing countries, including Indonesia.

Based on the results of the Basic Health Research (Riskedas) in 2018, the prevalence of hypertension based on measurements in the population aged 18 years was $34.1 \%$, the highest was in South Kalimantan (44.1\%), while the lowest was in Papua (22.2\%). Hypertension occurs in the age group 31-44 years (31.6\%), age 45-54 years (45.3\%), age 55-64 years (55.2\%).

From the prevalence of hypertension of $34.1 \%$, it was known that $8.8 \%$ were diagnosed with hypertension and $13.3 \%$ of people diagnosed with hypertension did not take medication and $32.3 \%$ did not take medication regularly. This shows that most people with hypertension do not know that they are hypertension so they do not get treatment.

The reasons people with hypertension do not take medication are because people with hypertension feel healthy (59.8\%), irregular visits to health facilities $(31.3 \%)$, taking traditional medicine $(14.5 \%)$, using other therapies $(12.5 \%)$ ), forgetting to take medicine $(11.5 \%)$, unable to buy medicine $(8.1 \%)$, drug side effects $(4.5 \%)$, and hypertension medicine is not available at health facilities $(2 \%)$. 
Hypertension is called the silent killer because it is often without complaints, so the patient does not know he has hypertension and is only known after complications occur. Target organ damage due to complications of hypertension will depend on the magnitude of the increase in blood pressure and the duration of the undiagnosed and untreated blood pressure condition.

Hypertension prevalence in Banten Province still occupies the largest proportion of all reported PTM, which is $24.68 \%$. Number of the population at risk $>18$ years. The high incidence of hypertension in the community and the dangers of complications that can be caused by hypertension, therefore the author wants to examine "The Overview of Controlled and Uncontrolled Hypertension Incidence Rates at Malingping Health Center in January-March 2021"

\section{METHODS}

This study is a descriptive study that aims to describe the incidence of hypertension patients based on controlled and uncontrolled at Malingping Health Center. The location of this research was carried out at the Malingping Health Center from April 14 - April 15, 2021.

The population in this study were all hypertensive patients who came for treatment at the Malingping Health Center who had to total of 119 patients. Inclusion criteria: Patients who come to the Malingping Health Center with BP $\geq 140 \mathrm{mmHg}$, patients who come regularly for treatment and do not routinely seek treatment. Exclusion Criteria: Patients who came to the Malingping Health Center with BP $<140 \mathrm{mmHg}$. The sampling technique in this study used purposive sampling and this research data collection technique uses secondary data and primary data, which must be in the form of medical records of Hypertension patients at the Malingping Health Center in January-March 2021. The data collected includes name, age, gender, and treatment visits. The data will be processed using Data Processing (editing), Coding (Coding), Data Entry (Entry) techniques, Data Cleaning (Cleaning data).

\section{RESULTS AND DISCUSSION}

The results of this study will describe the description of the incidence of controlled and uncontrolled hypertension patients based on visits to the Malingping Health CenterThis research was carried out at the Malingping Health Center in January-March 2021. This data can be obtained from the patient's medical records conducted at the Malingping Health Center. Medical records used as samples were 119 medical records of hypertension patients.

The following are the results of the study which are presented in a tabular form consisting of several distributions of data according to age, sex, controlled and uncontrolled. 
Researchers classify controlled and uncontrolled Hypertension patients at the Malingping Health Center in January-March 2021, the results of the study can be seen in the following table:

Table 1. Frequency Distribution of Controlled and Uncontrolled Hypertension Patients at Malingping Health Center in January-March 2021

\begin{tabular}{ccc}
\hline & Frequency & Percentage ( \%) \\
\hline Not controlled & 106 & 81.1 \\
Controlled & 13 & 10.9 \\
\hline Total & $\mathbf{1 1 9}$ & $\mathbf{1 0 0}$ \\
\hline
\end{tabular}

From Table 1, it is known that based on the results of the study, it can be seen from 106 respondents who were not controlled $(81.1 \%)$, while those who were controlled were 13 respondents $(10.9 \%)$.

Researchers obtained data on the age of hypertension patients at the Malingping Health Center in January-March 2021. The results of the study can be seen in the following table:

Table 2. Frequency Distribution of Age of Hypertension Patients at Malingping Health Center

\begin{tabular}{ccc}
\hline Age & Frequency & Percentage ( \%) \\
\hline$<60$ Years & 57 & 47.9 \\
$>60$ Years & 62 & 52.1 \\
\hline Total & $\mathbf{1 1 9}$ & $\mathbf{1 0 0}$ \\
\hline
\end{tabular}

From Table 2, it is known that the lowest age prevalence of hypertension patients at Malingping Health Center in January-March $2021<60$ years is 57 samples (47.9\%), while age > 60 years is 62 samples $(52.1 \%)$.

Researchers grouped the gender of Hypertension patients at the Malingping Health Center in January-March 2021 into two categories, namely male and female. The results of the study can be seen in the following table:

Table 3. Frequency Distribution Gender of Hypertension Patients at Malingping Health Center in January-March 2021

\begin{tabular}{ccc}
\hline Gender & Frequency & Percentage (\%) \\
\hline Man & 31 & 26.1 \\
Girl & 88 & 73.9 \\
\hline Total & $\mathbf{1 1 9}$ & $\mathbf{1 0 0}$ \\
\hline
\end{tabular}

From Table 4.3, it is known that the gender of hypertension patients at Malingping Health Center In January-March 2021, there were more female patients, namely 88 samples $(73.9 \%)$ than male patients, namely 31 samples $(26.1 \%)$.

Based on the research results obtained from the analysis results show that the majority of respondents who suffer from hypertension are elderly ( $>60$ years) with a percentage of $52.1 \%$. 
According to the Indonesian Ministry of Health (2018), with increasing age, there is a decrease in physiological function and body resistance that occurs due to the aging process which can cause a person to be susceptible to diseases, one of which is hypertension.

One study in 2012 found that in the elderly aged 55-59 years with an age of 60-64 years there was an increase in hypertension by 2.18 times, aged 65-69 years 2.45 times, and aged $>70$ years 2.97 times. This happens because at that age the large arteries lose their flexibility and become stiff, because of that the blood in each heartbeat is forced to pass through the blood vessels that are narrower than usual and cause an increase in blood pressure.

The results of this study are in line with previous research by Sulistyowati (2010) and Artianingrum (2015) which concluded that there is a relationship between age and the incidence of hypertension. The study found that age $>40$ years had an 11.71 times risk of developing hypertension compared to age $<40$ years. ${ }^{12}$

Based on the research results obtained from the analysis results show that the majority of respondents who suffer from hypertension are female with a percentage of $73.9 \%$.

According to Anggraini (2012), on average, women will experience an increased risk of high blood pressure (hypertension) after menopause, namely over 45 years of age. Women who have not experienced menopause are protected by the hormone estrogen which plays a role in increasing HDL (High-Density Lipoprotein) levels. Low HDL cholesterol levels and high LDL (Low-Density Lipoprotein) cholesterol affect the process of atherosclerosis. This is in line with research conducted by Sarasati (2011) which proves that there is a relationship between gender and hypertension. In this study, it was found that the percentage of women with hypertension was more than men. ${ }^{12}$

Based on the results of the study obtained from the analysis results show that the majority of respondents who suffer from uncontrolled hypertension are 106 while those who are controlled are 13.

One of the studies in 2020 that controlled hypertension was clinically defined as systolic blood pressure $<140 / 90 \mathrm{mmHg}$ as a result of routine treatment with lifestyle modification or pharmacological therapy. Uncontrolled hypertension is a condition of hypertension that is not treated properly or is not controlled at blood pressure $>140 / 90 \mathrm{mmHg}$.

Hypertension or high blood pressure is an increase in systolic blood pressure of more than $140 \mathrm{mmHg}$ and diastolic blood pressure of more than $90 \mathrm{mmHg}$ on two measurements with an interval of five minutes in a state of sufficient rest/quiet. ${ }^{1}$

Hypertension is one of the main causes of mortality and morbidity in Indonesia, so the management of this disease is a very common intervention carried out at various levels of health facilities. ${ }^{1}$ 
The division of the severity of hypertension in a person is one of the basics for determining the management of hypertension (adapted from A Statement by the American Society of Hypertension and the International Society of Hypertension 2013).

\begin{tabular}{|l|l|l|l|l|}
\hline Class & \multicolumn{1}{|c|}{$\begin{array}{c}\text { Systolic blood } \\
\text { pressure }(\mathbf{m m H g})\end{array}$} & \multicolumn{1}{c|}{$\begin{array}{c}\text { Diastolic blood } \\
\text { pressure (mmHg) }\end{array}$} \\
\hline Optimal & $<120$ & AND & $<80$ \\
\hline Normal & $120-129$ & AND/OR & $80-84$ \\
\hline High normal & $130-139$ & AND/OR & $85-89$ \\
\hline Grade 1 hypertension & $140-159$ & AND/OR & $90-99$ \\
\hline Grade 2 hypertension & $160-179$ & AND/OR & $100-109$ \\
\hline Grade 3 hypertension & $\geq 180$ & AND/OR & $\geq 110$ \\
\hline $\begin{array}{l}\text { Isolated systolic } \\
\text { hypertension }\end{array}$ & $\geq 140$ & AND & $<90$ \\
\hline
\end{tabular}

\section{Figure 1. Classification of Hypertension}

\section{Source: Guidelines for the Management of Hypertension in Cardiovascular Disease}

Hypertension based on cause is divided into 2, namely: ${ }^{5}$ Primary Hypertension/Essential Hypertension: Hypertension whose cause is unknown (idiopathic), although it is associated with a combination of lifestyle factors such as lack of movement (inactivity) and diet. Occurs in about $90 \%$ of patients with hypertension. Secondary Hypertension/Non-Essential Hypertension: Hypertension with a known cause. In about $5-10 \%$ of patients with hypertension, the cause is kidney disease. In about $1-2 \%$, the cause is hormonal disorders or the use of certain drugs (eg birth control pills).

In general, hypertension has no specific cause. Hypertension occurs in response to an increase in cardiac output or an increase in peripheral pressure. However, several factors influence the occurrence of hypertension, including: ${ }^{6} 1$. Gender: The prevalence of hypertension in men is the same as in women. However, women are protected from cardiovascular disease before menopause, one of which is coronary heart disease. ${ }^{7}$ Women who have not experienced menopause are protected by the hormone estrogen which plays a role in increasing levels of High-Density Lipoprotein (HDL). High levels of HDL cholesterol are a protective factor in preventing the process of atherosclerosis. The protective effect of estrogen is thought to explain the presence of premenopausal female immunity. In premenopause women begin to lose little by little the hormone estrogen which has been protecting blood vessels from damage.

This process continues where the estrogen hormone changes in quantity according to the age of the woman naturally, which generally begins to occur in women aged 45-55 years. 2. Age: Blood 
pressure in the elderly (elderly) will tend to be high so that the elderly are at greater risk of developing hypertension. Increasing age causes blood pressure to increase because arterial walls in old age will experience thickening which will result in a buildup of collagen substances in the muscle layer, so that blood vessels will gradually narrow and become stiff. Age is one of the factors that affect blood pressure. Age is related to high blood pressure because the older a person is, the greater the risk of someone developing hypertension. One study in 2009 found that in the elderly aged 55-59 years with an age of 60-64 years there was an increase in hypertension by 2.18 times, aged 65-69 years 2.45 times, and aged $>70$ years 2.97 times. This happens because at that age the large arteries lose their flexibility and become stiff. Therefore, the blood with each heartbeat is forced to pass through the blood vessels that are narrower than usual and cause an increase in blood pressure. 3. Genetics: The presence of genetic factors in certain families will cause that family to have a risk of suffering from hypertension. This is associated with an increase in intracellular sodium levels and a low ratio of potassium to sodium. Individuals with parents with hypertension have twice the risk of developing hypertension than people without a family history of hypertension. ${ }^{4}$ essential hypertension with a family history of hypertension. 5. Use of Sodium With Hypertension: Sodium functions in maintaining fluid balance in the body (extracellular). Sodium regulates osmotic pressure which keeps fluid from leaving the blood and into cells. If the amount of sodium in the cell increases excessively, water will enter the cell, as a result, the cell will swell. This is what causes swelling in body tissues.

The fluid balance will also be disturbed if a person loses sodium. Water will enter the cell to dilute the sodium in the cell. Extracellular fluid will decrease. This change will lower blood pressure, sodium can also maintain acid-base balance in the body, muscle and nerve sensitivity, which plays a role in nerve transmission that results in muscle contractions, plays a role in glucose absorption, and acts as a means of transporting nutrients through membranes, especially through the intestinal wall. Sodium is associated with high blood pressure because consumption of high amounts of sodium can shrink the diameter of the arteries, so the heart has to pump harder and push the increased volume of blood through the narrower spaces and will cause blood pressure to increase. The effect of sodium intake on high blood pressure occurs through an increase in plasma volume and blood pressure. Sodium is the main cation in the extracellular fluid that plays an important role in maintaining plasma and extracellular volume. High sodium intake can cause the sodium concentration in the extracellular fluid to increase so that to normalize the intracellular fluid is withdrawn. out and result in an increase in blood volume and an impact on increasing blood pressure. 6. Obesity: Bodyweight is a determinant of blood pressure in most ethnic groups of all ages. According to the National Institutes for Health USA (NIH, 1998), the prevalence of high blood pressure in people with a Body Mass Index (BMI) $>30$ (obese) was $38 \%$ for men and $32 \%$ for women, compared with a prevalence of $18 \%$ for men and 
$17 \%$ for women who have a BMI $<25$ (normal nutritional status according to international standards). ${ }^{4} 4$ According to Hall (1994) physiological changes can explain the relationship between excess body weight and blood pressure, namely the occurrence of insulin resistance and hyperinsulinemia, activation of the sympathetic nervous system and the renin-angiotensin system, and physical changes in the kidneys. ${ }^{4}$

Blood pressure is affected by stroke volume and total peripheral resistance. If there is an increase in one of these variables that are not compensated, it can cause hypertension. The body has a system that functions to prevent acute changes in blood pressure caused by circulation disorders and maintain blood pressure stability in the long term. The blood pressure control system is very complex. Control starts from rapid reaction systems such as cardiovascular reflexes through the nervous system, chemoreceptor reflexes, ischemic responses, central nervous system originating from the atria, and smooth muscle pulmonary arteries. While the slow reaction control system through the movement of fluid between the capillary circulation and the interstitial space is controlled by the hormones angiotensin and vasopressin.

The mechanism of hypertension is through the formation of angiotensin II from angiotensin I by angiotensin I converting enzyme (ACE). ACE plays an important physiological role in regulating blood pressure. Blood contains angiotensinogen which is produced in the liver. Furthermore, by hormones, renin (produced by the kidneys) will be converted into angiotensin I. By ACE in the lungs, angiotensin I am converted into angiotensin II. Angiotensin II is what has a key role in raising blood pressure through two main actions

The first action is to increase the secretion of antidiuretic hormone (ADH) and thirst. ADH is produced in the hypothalamus (pituitary gland) and acts on the kidneys to regulate osmolality and urine volume. With increased $\mathrm{ADH}$, very little urine is excreted out of the body (antidiuresis), so becomes concentrated and has a high osmolality. To dilute it, the volume of extracellular fluid will be increased by pulling fluid from the intracellular compartment. As a result, blood volume increases which in turn will increase blood pressure

The second action is to stimulate the secretion of aldosterone from the adrenal cortex. Aldosterone is a steroid hormone that has an important role in the kidneys. To regulate the volume of extracellular fluid, aldosterone will reduce the excretion of $\mathrm{NaCl}$ (salt) by reabsorbing it from the renal tubules. Increasing the concentration of $\mathrm{NaCl}$ will be diluted again by increasing the volume of extracellular fluid which in turn will increase blood volume and pressure.

The clinical manifestations that can arise due to hypertension according to Elizabeth J. Corwin are that most of the clinical symptoms arise after experiencing hypertension for years. Clinical manifestations that arise can include headache when awake which is sometimes accompanied by 
nausea and vomiting due to increased intracranial blood pressure, blurred vision due to retinal damage, unstable step swing due to damage to the nervous system, nocturia (increased urination at night) due to increased blood flow. renal blood and glomerular filtration, dependent edema due to increased capillary pressure. Involvement of cerebral vessels can lead to stroke or transient ischemic attack manifesting as transient paralysis of one side or hemiplegia or visual disturbances. Another symptom that is often found is epistaxis,

In establishing a diagnosis of hypertension, several stages of the examination are needed that must be undertaken before determining the therapy or treatment to be taken. This diagnostic algorithm was adapted from the Canadian Hypertension Education Program. The Canadian Recommendation for The Management of Hypertension 2014. ${ }^{10}$

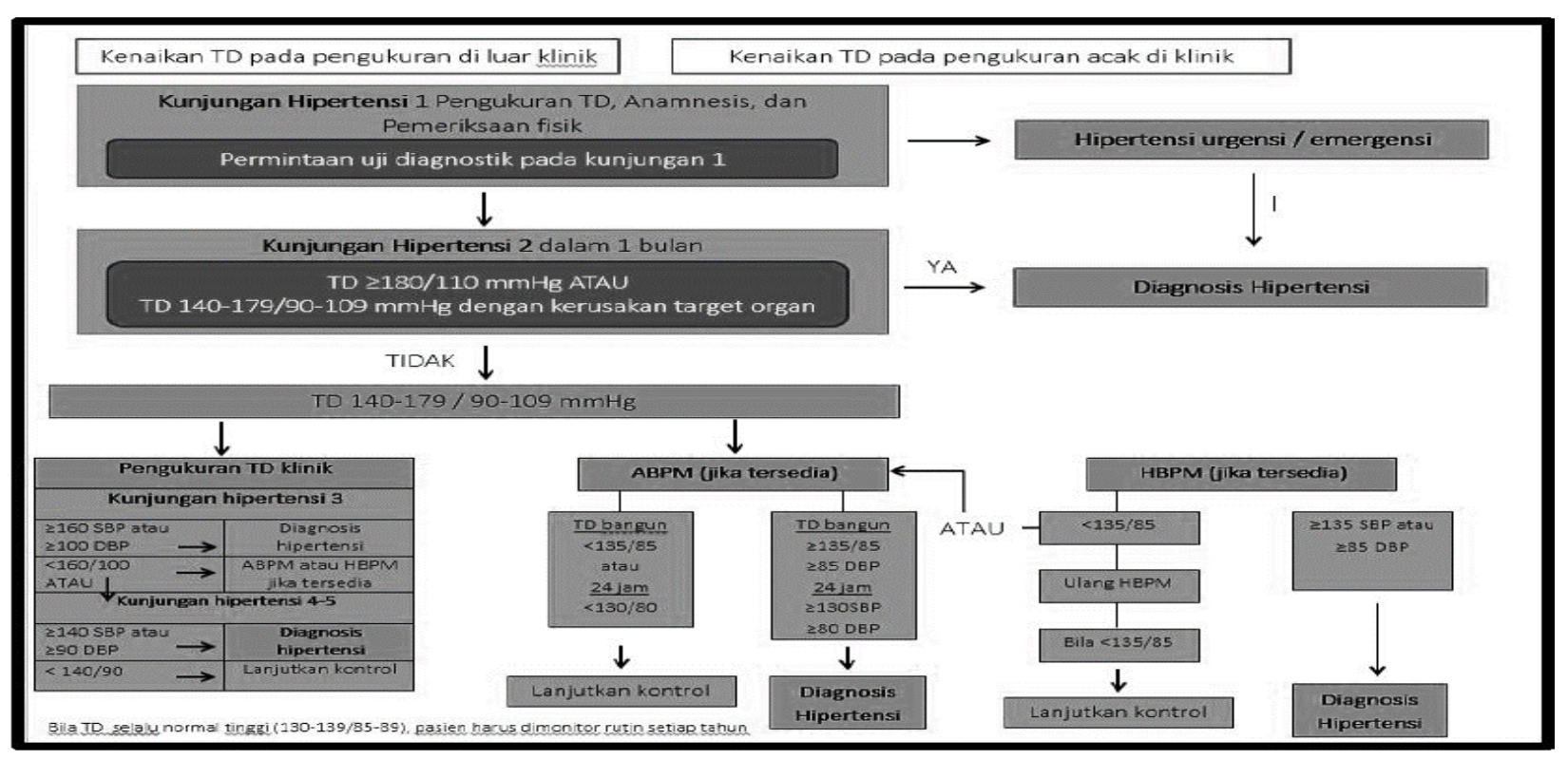

Figure 2. Hypertension diagnosis algorithm (adapted from Canadian Hypertension Education Program: The Canadian Recommendation for The Management of Hypertension 2014)

Hypertension is a major risk factor for heart disease, congestive heart failure, stroke, visual impairment, and kidney disease. High blood pressure generally increases the risk of these complications. Untreated hypertension will affect all organ systems and ultimately shorten life expectancy by 10-20 years. 20 Mortality in hypertensive patients is faster if the disease is not controlled and has caused complications to several vital organs. The causes of death that often occur are heart disease with or without stroke and kidney failure

Complications that occur in mild and moderate hypertension affect the eyes, kidneys, heart, and brain. In the eyes in the form of retinal hemorrhages, visual disturbances to blindness. Heart failure is a disorder that is often found in severe hypertension in addition to coronary and myocardial disorders. 
where there is bleeding caused by the rupture of a microaneurysm which can lead to death. Other abnormalities that can occur are thromboembolic processes and transient ischemic attacks (TIA). Renal failure is often seen as a complication of long-standing hypertension and in an acute process such as malignant hypertension

Hypertension can cause damage to organs, either directly or indirectly. Several studies have found that the cause of damage to these organs can be through a direct result of an increase in blood pressure in the organ, or because of an indirect effect, including the presence of autoantibodies against the angiotensin II receptor, oxidative stress. Other studies have also shown that a high-salt diet and sensitivity to salt play a major role in the occurrence of target organ damage, such as blood vessel damage due to increased expression of transforming growth factor- $\beta$ (TGF- $\beta$ ). 9 Brain: Stroke is damage to target organs in the brain caused by hypertension. A stroke occurs due to bleeding, elevated intracranial pressure, or an embolus released from a non-brain vessel exposed to high pressure. Stroke can occur in chronic hypertension when the arteries that supply the brain are hypertrophied or thickened, so that blood flow to the areas that are supplied with blood will be reduced. The arteries in the atherosclerotic brain weaken, increasing the likelihood of an aneurysm forming. Encephalopathy can also occur, especially in malignant hypertension or fast-onset hypertension. The high pressure in these disorders causes an increase in capillary pressure, thus pushing fluid into the interstitial spaces throughout the brain. central nervous system.

Cardiovascular: Myocardial infarction can occur when a coronary artery is atherosclerotic or when a thrombus forms that blocks blood flow through these blood vessels so that the myocardium does not get an adequate oxygen supply. Myocardial oxygen demand is not met causing cardiac ischemia, which in turn can lead to infarction

Kidney: Chronic kidney disease can occur due to progressive damage due to high pressure in the renal capillaries and glomerulus. Glomerular damage will cause blood to flow to the functional units of the kidney so that the nephrons will be disrupted and continue to cause hypoxia and kidney death. Damage to the glomerular membrane will also cause the protein to be excreted through the urine so that edema is often found as a result of reduced plasma colloid osmotic pressure. This is especially true in chronic hypertension

Retinopathy: High blood pressure can cause damage to blood vessels in the retina. The higher the blood pressure and the longer hypertension lasts, the more severe the damage that can be caused. Other disorders of the retina that occur due to high blood pressure are ischemic optic neuropathy or damage to the optic nerve due to poor blood flow, retinal artery and vein occlusion due to blockage of blood flow to the retinal arteries and veins. Patients with hypertensive retinopathy are asymptomatic at first, which can eventually lead to blindness in the late stages 
More severe damage to the eye occurs in the condition of malignant hypertension, in which blood pressure rises suddenly. Clinical manifestations due to malignant hypertension also occur suddenly, including headache, double vision, dim vision, and sudden vision loss. ${ }^{11}$

Management of hypertension consists of Non-Pharmacology and Pharmacology. NonPharmacology i.e.Living a healthy lifestyle has been proven to lower blood pressure, and is generally very beneficial in reducing the risk of cardiovascular problems. In patients with grade 1 hypertension, without other cardiovascular risk factors, a healthy lifestyle strategy is an early stage of treatment, which must be followed. for at least 4-6 months. If after this period, the expected reduction in blood pressure is not found or other cardiovascular risk factors are found, it is strongly recommended to start pharmacological therapy.

Some of the healthy lifestyles recommended by many guidelines are: Weight loss, replacing unhealthy foods by increasing the intake of vegetables and fruits can provide more benefits besides lowering blood pressure, such as avoiding diabetes and dyslipidemia, reducing salt intake. In our country, foods high in salt and fat are traditional foods in most regions. Not infrequently patients are not aware of the salt content in fast food, canned food, processed meat, and so on. Not infrequently, a lowsalt diet is also useful for reducing the dose of antihypertensive drugs in patients with hypertension grade 2. It is recommended that salt intake does not exceed $2 \mathrm{~g} /$ day, 5 exercises that are done regularly as much as 30-60 minutes/day, at least 3 days/day. Sunday can help lower blood pressure. For patients who do not have time to exercise specifically, should still be encouraged to walk, ride a bicycle or climb stairs in their routine activities at work, reducing alcohol consumption. Although alcohol consumption has not become a common lifestyle in our country, alcohol consumption is increasing day by day along with the development of relationships and lifestyles, especially in big cities. Consumption of alcohol more than 2 drinks per day in men or 1 drink per day in women, can increase blood pressure. Thus limiting or stopping alcohol consumption helps lower blood pressure. should still be encouraged to walk, ride a bicycle or climb stairs in their routine activities at work, reduce alcohol consumption. Although alcohol consumption has not become a common lifestyle in our country, alcohol consumption is increasing day by day along with the development of relationships and lifestyles, especially in big cities. Consumption of alcohol more than 2 drinks per day in men or 1 drink per day in women, can increase blood pressure. Thus limiting or stopping alcohol consumption helps lower blood pressure. should still be encouraged to walk, ride a bicycle or climb stairs in their routine activities at work, reduce alcohol consumption. Although alcohol consumption has not become a common lifestyle in our country, alcohol consumption is increasing day by day along with the development of relationships and lifestyles, especially in big cities. Consumption of alcohol more than 2 drinks per day in men or 1 drink per day in women, can increase blood pressure. Thus limiting or stopping alcohol consumption helps lower blood pressure. but 
alcohol consumption is increasing day by day along with the development of society and lifestyle, especially in big cities. Consumption of alcohol more than 2 drinks per day in men or 1 drink per day in women, can increase blood pressure. Thus limiting or stopping alcohol consumption helps lower blood pressure. but alcohol consumption is increasing day by day along with the development of society and lifestyle, especially in big cities. Consumption of alcohol more than 2 drinks per day in men or 1 drink per day in women, can increase blood pressure. Thus limiting or stopping alcohol consumption helps lower blood pressure. Quit smoking. Although this has not been proven to have a direct effect on lowering blood pressure, smoking is one of the main risk factors for cardiovascular disease, and patients should be advised to stop smoking.

Pharmacology is In general, pharmacological therapy for hypertension is started if the patient with hypertension grade 1 does not experience a decrease in blood pressure after $>6$ months of living a healthy lifestyle and in patients with hypertension grade 2 . Some basic principles of pharmacological therapy that need to be considered to maintain compliance and minimize side effects, that is 11 if possible, give a single dose of the drug, give generic (non-patent) drugs if appropriate and can reduce costs, give medicine to elderly patients (over the age of 80 years) such as at the age of 55-80 years, taking into account comorbid factors, do not combine angiotensin-converting enzyme inhibitors (ACE-i) with angiotensin II receptor blockers (ARBs), Provide comprehensive education to patients regarding pharmacological therapy, ldo regular monitoring of drug side effects.

The hypertension management algorithm recommended by various guidelines has the same principle, and below is the general hypertension management algorithm, which is regulated from A Statement by the American Society of Hypertension and the International Society of Hypertension 2013; 


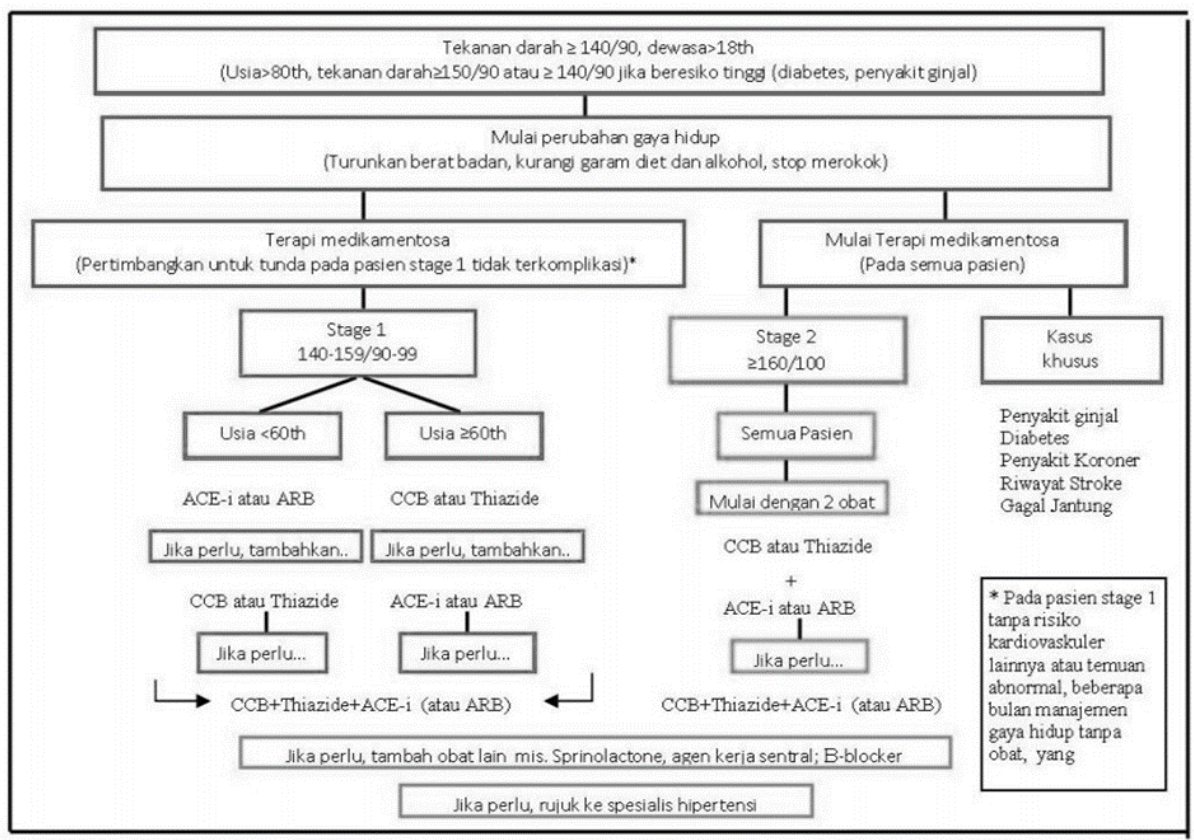

Figure 3. Treatment Flow for Hypertension

Source: Guidelines for the Management of Hypertension in Cardiovascular Disease

Beta-blockers are the drug of the first choice in the management of hypertension in patients with coronary heart disease, especially those that cause angina symptoms. This drug will work to reduce ischemia and angina because its main effect is a negative inotropic and chronotropic. As the heart rate decreases, the diastolic filling time for coronary perfusion will be prolonged. Beta-blockers also inhibit the release of renin in the kidneys which will inhibit the occurrence of heart failure. Cardioselective beta-blockers $(\beta 1)$ are recommended because they have no intrinsic sympathomimetic activity. $^{11}$

CCB will be used as an additional drug after optimization of beta-blocker dose, if there is: ${ }^{3}$ TD that stays high, persistent angina, know of absolute contraindications to the administration of betablockers.

CCBs work to reduce myocardial oxygen demand by lowering peripheral vascular resistance and lowering blood pressure. In addition, CCBs will also increase myocardial oxygen supply with coronary vasodilating effects. It should be borne in mind that although CCBs are useful in the management of angina, there is no recommendation to date that these drugs play a role in the prevention of cardiovascular events in patients with coronary heart disease.

The use of ACEi in coronary heart disease patients with diabetes mellitus with or without impaired left ventricular systolic function is the main choice with full recommendations from all 
published guidelines. The administration of this drug is particularly beneficial in coronary heart patients with hypertension, especially in the prevention of cardiovascular events.

In elderly hypertensive patients (> 65 years), ACEi administration is also recommended, especially after the publication of 2 large studies namely ALLHAT and ANBP-2., although both drugs have the same reduction in blood pressure.

The indication for ARBs is in patients who are intolerant to ACEi. Several large studies have shown that valsartan and captopril are equally effective in post-myocardial infarction patients with a high risk of cardiovascular events. ${ }^{2}$

Thiazide diuretics will reduce the risk of cardiovascular events, as has been stated by several previous studies, such as Veterans Administrations Studies, MRC, and SHEP.

Indications for long-acting nitrates are for the management of uncontrolled angina with adequate doses of beta-blockers and CCBs in patients with coronary heart disease. However, to date, no data are suggesting the use of nitrates in the management of hypertension, other than in combination with hydralazine in certain cases.

\begin{tabular}{|c|c|c|c|c|}
\hline Faktor risiko, & Tekanan dal & Ih (mmHg) & & \\
\hline $\begin{array}{l}\text { kerusakan } \\
\text { target oran } \\
\text { yang } \\
\text { asimomatik } \\
\text { atau penyakit }\end{array}$ & $\begin{array}{l}\text { Normal } \\
\text { tinggi } \\
\text { (TDS } 130 \\
-139 \\
\text { atau TDD } \\
85-89 \text { ) }\end{array}$ & $\begin{array}{l}\text { Hipertensi } \\
\text { derajat I } \\
\text { (TDS } 130- \\
\text { 139 } \\
\text { atau TDD } 85 \\
-89 \text { ) }\end{array}$ & $\begin{array}{l}\text { Hipertensi } \\
\text { derajat II } \\
\text { (TDS } 130- \\
\text { 139 } \\
\text { atau TDD } 85 \\
\text { - 89) }\end{array}$ & $\begin{array}{l}\text { Hipertensi } \\
\text { derajat III } \\
\text { (TDS } 130- \\
\text { 139 } \\
\text { atau TDD } 85 \\
-89 \text { ) }\end{array}$ \\
\hline Tanpa FR lain & & $\begin{array}{l}\text { Risiko } \\
\text { rendah }\end{array}$ & $\begin{array}{l}\text { Risiko } \\
\text { sedang }\end{array}$ & Risiko tinggi \\
\hline $1-2 \mathbf{F R}$ & $\begin{array}{l}\text { Risiko } \\
\text { rendah }\end{array}$ & $\begin{array}{l}\text { Risiko } \\
\text { sedang }\end{array}$ & $\begin{array}{l}\text { Risiko } \\
\text { sedang } \\
\text { tinggi }\end{array}$ & Risiko tinggi \\
\hline$\geq \mathbf{3} \mathbf{F R}$ & $\begin{array}{l}\text { Risiko } \\
\text { rendah } \\
\text { sedang }\end{array}$ & $\begin{array}{l}\text { Risiko } \\
\text { sedang } \\
\text { tinggi }\end{array}$ & Risiko tinggi & Risiko ringgi \\
\hline $\begin{array}{l}\text { OD, CKD std } 3 \\
\text { atau DM }\end{array}$ & $\begin{array}{l}\text { Risiko } \\
\text { sedang } \\
\text { tinggi }\end{array}$ & Risiko tinggi & Risiko tinggi & $\begin{array}{l}\text { Risiko tinggi } \\
-- \\
\text { tinggi }\end{array}$ \\
\hline $\begin{array}{l}\text { CVD } \\
\text { simtomatik, } \\
\text { CKD } \geq \text { std } 4 \\
\text { atau } \\
\text { dengan OM } \\
\text { FR }\end{array}$ & $\begin{array}{l}\text { Risiko } \\
\text { sangat } \\
\text { tinggi }\end{array}$ & $\begin{array}{l}\text { Risiko } \\
\text { sangat tinggi }\end{array}$ & $\begin{array}{l}\text { Risiko } \\
\text { sangat tinggi }\end{array}$ & $\begin{array}{l}\text { Risiko } \\
\text { sangat tinggi }\end{array}$ \\
\hline
\end{tabular}

Figure 4. Risk Factors and Blood Pressure

Using a formal calculation of cardiovascular risk estimation (ESC 2013), to determine the prognosis. Always look for metabolic risk factors (diabetes, thyroid disorders, and others) in patients with hypertension with or without cardiovascular disease.

Lifestyle modifications can be done by limiting salt intake to no more than - teaspoon (6 grams/day), losing weight, avoiding caffeinated drinks, cigarettes, and alcoholic beverages. Exercise is also recommended for people with hypertension, can be in the form of walking, running, jogging, 
cycling for 20-25 minutes with a frequency of 3-5 times per week. It is also important to get enough rest (6-8 hours) and control stress. Some foods that should be avoided or limited by people with hypertension are: ${ }^{13}$ Foods that contain high levels of saturated fat (brain, kidney, lung, coconut oil, lard), foods that are processed using sodium salt (biscuits, crackers, chips, and salty dry foods), canned foods and beverages (sardines, sausages, corned beef, canned vegetables and fruits, soft drinks), preserved foods (jerky)

\section{CONCLUSION AND SUGGESTIONS}

The incidence of hypertension sufferers in the working area of the Malingping Health Center is still a lot that is not controlled. It can be seen from month to month that hypertension sufferers tend to receive routine treatment, namely, in February there are 2, in January there are 6, and in March there are 5 people. Therefore, it is necessary to promote health to control and prevent complications from hypertension.

In the area around the Malingping Health Center, it is necessary to improve health promotion, especially as an effort to prevent primary and secondary hypertension in the community, and health workers are expected to be able to understand the basic pillars of hypertension when carrying out promotive, preventive and curative efforts.

\section{THANK-YOU NOTE}

Thank you to all who have participated in the preparation of the manuscript, especially the supervisors, midwives, and nurses of the Malingping Health Center who have provided the opportunity and support for me in the preparation of this manuscript.

\section{REFERENCES}

1. Information Center for Data and Information Ministry of Health RI. 2014. Hypertension is the biggest challenge in Indonesia. Jakarta. (Accessed from www.depkes.go.id.).

2. Department Health. 2018. Report on the Results of Basic Health Research (Riskesdas) Indonesia2018. MOH RI: Jakarta.

3. Ministry of Health of the Republic of Indonesia. 2017. Most Hypertension Patients Don't Realize It..(Accessed fromhttp://www.depkes.go.id).

4. Anarini. 2012. Nutrition Therapy of Elderly Patients Treated in Hospitals. In: Harjodisastro D, Syam AF, Sukrisman L, editor. Nutritional Support in Cases of Internal Medicine. Jakarta: Department of Internal Medicine, Faculty of Medicine UI.

5. Budijanto, Didik and Dwi, Anggaeni (2000), Analysis of Hypertension Trends in Relation to Age and Body Mass Index, Trisakti Medical Journal Vol.19 No.1, Jakarta. Anggraeni, DM, \& 
Saryono., 2013. Qualitative and Quantitative Research Methodology in the field of Health, Nuha Medika, Yogyakarta.

6. Arikunto, S., 2011. Research Procedure A Practical Approach Revision 8 Edition, Rineka Cipta, Jakarta.

7. Bustan, MN, 2007. Epidemiology: Non-Communicable Diseases, Issue 2, Rineka Cipta, Jakarta.

8. Aris, S. 2015. Mayo Clinic. Hypertension, Overcoming High Blood Pressure. PT Intisari Mediatama : Jakarta.

9. Dalimartha, S. 2011. Care Your Self Hypertension. Jakarta: Spreader Plus.

10. Mustamine. 2010. Sodium Intake, Nutritional Status and High Blood Pressure in the Elderly. Journal of Food Nutrition Media. Volume IX. Edition 1: Makassar.

11. Notoatmodjo, S. 2003. Public Health Sciences. Rineka Cipta: Jakarta.

12. Pradono J. 2010. Factors Affecting the Occurrence of Hypertension in Urban Areas (Data Analysis of Riskesdas 2007). Gizi Indonesia 2010, 33(1):59-66. 